\title{
Catechin synergistically potentiates mast cell-stabilizing property of caffeine
}

\author{
Misaki Yashima ${ }^{\dagger}$, Yukine Sato ${ }^{\dagger}$ and Itsuro Kazama* ${ }^{*}$
}

\begin{abstract}
Caffeine and catechin, contained in coffee and tea, are commonly consumed substances worldwide. Studies revealed their health promoting functions, such as anti-oxidant, anti-cancer and anti-bacterial properties. Additionally, studies also revealed their roles in ameliorating the symptoms of allergic disorders, indicating their anti-allergic properties. In the present study, using the differential-interference contrast (DIC) microscopy, we examined the effects of caffeine and catechin on the degranulation from rat peritoneal mast cells. Both caffeine and catechin dose-dependently decreased the numbers of degranulating mast cells. At concentrations equal to or higher than $25 \mathrm{mM}$, caffeine and catechin markedly suppressed the numbers of degranulating mast cells. In contrast, at relatively lower concentrations, both substances did not significantly affect the numbers of degranulating mast cells. However, surprisingly enough, low concentrations of catechin $(1,2.5 \mathrm{mM})$ synergistically enhanced the suppressive effect of $10 \mathrm{mM}$ caffeine on mast cell degranulation. These results provided direct evidence for the first time that caffeine and catechin dosedependently inhibited the process of exocytosis. At relatively lower concentrations, caffeine or catechin alone did not stabilize mast cells. However, low concentrations of catechin synergistically potentiated the mast cell-stabilizing property of caffeine.
\end{abstract}

Keywords: Caffeine, Catechin, Exocytosis, Mast cells, Mast cell, Stabilizing property

\section{To the editor,}

Caffeine, a psychoactive alkaloid contained in coffee, and catechin, a polyphenolic flavonoid in tea, are commonly consumed substances worldwide [1, 2]. Previous studies revealed their health promoting functions, including anti-oxidant, anti-cancer and anti-bacterial properties [3, 4]. Additionally, both in humans or experimental animal models, recent studies also revealed their roles in ameliorating the symptoms of allergic disorders, such as bronchial asthma and anaphylaxis [5-8]. These studies indicated anti-allergic properties of caffeine and catechin, showing their additional pharmacological potency. In our previous studies, by continuously monitoring the process of

*Correspondence: kazamai@myu.ac.jp

${ }^{\dagger}$ Misaki Yashima and Yukine Sato contributed equally to this article Miyagi University, School of Nursing, 1-1 Gakuen, Taiwa-cho,

Kurokawa-gun, Miyagi 981-3298, Japan exocytosis in mast cells, we provided in vitro evidence that anti-allergic drugs, anti-microbial drugs and corticosteroids exert mast cell-stabilizing properties [9-13]. In the present study, to elucidate the mechanisms underlying the anti-allergic properties of caffeine and catechin, we directly examined their effects on the degranulation from rat peritoneal mast cells.

In mast cells isolated from the peritoneal cavity of male Wistar rats (CLEA Japan Inc., Tokyo, Japan), we externally induced exocytosis by compound 48/80 (Sigma-Aldrich; final concentration $10 \mu \mathrm{g} / \mathrm{ml}$ ) in the presence or absence of caffeine or catechin. Caffeine anhydrous, purchased from Wako Pure Chem Ind. (Osaka, Japan), was dissolved in the external solution at the final concentrations of $1 \mathrm{mM}(194 \mu \mathrm{g} / \mathrm{ml}), 5 \mathrm{mM}$ $(971 \mu \mathrm{g} / \mathrm{ml}), 10 \mathrm{mM}(1.94 \mathrm{mg} / \mathrm{ml}), 25 \mathrm{mM}(4.86 \mathrm{mg} / \mathrm{ml})$, $50 \mathrm{mM}(9.71 \mathrm{mg} / \mathrm{ml})$ and $100 \mathrm{mM}(19.4 \mathrm{mg} / \mathrm{ml})$. D-(+)catechin hydrate, purchased from Nacalai Tesque Inc. 
(Kyoto, Japan), was dissolved in the external solution at the final concentrations of $1 \mathrm{mM}(290 \mu \mathrm{g} / \mathrm{ml}), 2.5 \mathrm{mM}$ (726 $\mu \mathrm{g} / \mathrm{ml}), 5 \mathrm{mM}(1.45 \mathrm{mg} / \mathrm{ml}), 10 \mathrm{mM}(2.90 \mathrm{mg} / \mathrm{ml})$ and $25 \mathrm{mM}(7.26 \mathrm{mg} / \mathrm{ml})$. As we described previously [9-13], bright-field images were obtained from randomly chosen $0.1-\mathrm{mm}^{2}$ fields of view (10 views from each condition). Using the differential-interference contrast (DIC) microscopy, we counted degranulated mast cells and calculated their ratio to all mast cells (Table 1). Degranulated mast cells were defined as cells surrounded by more than 8 granules outside the cell membrane as described previously [14]. Data were analyzed by Microsoft Excel (Microsoft Corporation, Redmond, Wash., USA) and reported as means \pm SD. Statistical significance was assessed by two-way ANOVA. A value of $p<0.05$ was considered significant.

Mast cells incubated in the external solution alone or relatively lower concentrations of caffeine $(1,5 \mathrm{mM})$ showed many wrinkles on their cell surface and released secretory granules as a result of exocytosis Fig. $1 \mathrm{Ab}-\mathrm{d}$ vs. a). However, in mast cells incubated in relatively higher concentrations of caffeine $(10,25,50,100 \mathrm{mM})$, such findings suggestive of exocytosis were partially or completely absent (Fig. 1Ae, f, g, h). Quantitatively, relatively lower concentrations of caffeine (1,5 mM) did not affect the numbers of degranulating mast cells (Fig. 1B). However, $10 \mathrm{mM}$ caffeine significantly decreased the number of degranulating mast cells (control, $95.4 \pm 7.70 \%$ vs. $10 \mathrm{mM}$ caffeine, $64.7 \pm 23.3 \%$; $n=10, P<0.05)$, and concentrations equal to or higher than $25 \mathrm{mM}$ more markedly reduced the numbers of degranulating cells ( $25 \mathrm{mM}$ caffeine, $21.8 \pm 6.96 \%$; $50 \mathrm{mM}$ caffeine, $14.3 \pm 3.70 \% ; 100 \mathrm{mM}$ caffeine, $11.1 \pm 5.62 \% ; n=10, P<0.05$; Fig. 1B). Similarly to the findings obtained from caffeine, relatively lower concentrations of catechin $(1,2.5 \mathrm{mM})$ did not affect the degranulation of mast cells (Fig. 2Ab, c, d) and the numbers of which were almost comparable to those incubated in the external solution alone (Fig. 2B). However, catechin with concentrations equal to or higher than $5 \mathrm{mM}$ partially or entirely halted the process of exocytosis (Fig. 2Ae, f, g) and significantly suppressed the numbers of degranulating mast cells (control, $97.7 \pm 2.56 \%$ vs. $5 \mathrm{mM}$ catechin, $84.1 \pm 6.47 \%$; $10 \mathrm{mM}$ catechin, $77.4 \pm 9.18 \% ; n=10, P<0.05$; Fig. $2 \mathrm{~B})$. Twenty-five $\mathrm{mM}$ catechin alone showed a marked reduction of the number of degranulating mast cells $(35.5 \pm 10.7 \%, n=10, P<0.05)$.

Previous studies indirectly determined the mast cellstabilizing properties of caffeine or catechin by measuring the amount of chemical mediators released from mast cells $[5,6,15]$. However, besides their exocytotic release

Table 1 Summary of mast cell counts in external solutions containing caffeine or catechin

\begin{tabular}{llll}
\hline Substances & $\begin{array}{l}\text { Degranulating mast cell counts/ } \\
\text { view }\end{array}$ & All mast cell counts/view & $\begin{array}{l}\text { Degranulating } \\
\text { mast cell ratio } \\
\text { (\%) }\end{array}$ \\
\hline External solution (control) & & & $95.4 \pm 7.70$ \\
$1 \mathrm{mM}$ caffeine & $26.0 \pm 3.30$ & $27.4 \pm 4.01$ & $97.9 \pm 1.50$ \\
$5 \mathrm{mM}$ caffeine & $84.3 \pm 13.7$ & $86.2 \pm 14.7$ & $96.6 \pm 2.88$ \\
$10 \mathrm{mM}$ caffeine & $59.8 \pm 17$ & $61.8 \pm 17.7$ & $64.7 \pm 23.3$ \\
$25 \mathrm{mM}$ caffeine & $30.9 \pm 14.9$ & $46.7 \pm 9.26$ & $21.8 \pm 6.96$ \\
$50 \mathrm{mM}$ caffeine & $10.8 \pm 3.99$ & $49.6 \pm 9.19$ & $14.3 \pm 3.70$ \\
100 mM caffeine & $5.10 \pm 2.28$ & $36.0 \pm 15.0$ & $11.1 \pm 5.62$ \\
External solution (control) & $4.90 \pm 2.64$ & $45.2 \pm 13.5$ & $97.7 \pm 2.56$ \\
$1 \mathrm{mM}$ catechin & $42.5 \pm 8.67$ & $43.5 \pm 8.78$ & $93.5 \pm 3.23$ \\
$2.5 \mathrm{mM}$ catechin & $81.2 \pm 12.7$ & $87.0 \pm 14.3$ & $90.0 \pm 3.83$ \\
$5 \mathrm{mM}$ catechin & $35.0 \pm 5.21$ & $39.0 \pm 6.32$ & $84.1 \pm 6.47$ \\
$10 \mathrm{mM}$ catechin & $50.0 \pm 7.16$ & $60.0 \pm 11.1$ & $77.4 \pm 9.18$ \\
$25 \mathrm{mM}$ catechin & $33.5 \pm 10.1$ & $43.2 \pm 12.4$ & $35.5 \pm 10.7$ \\
External solution (control) & $17.8 \pm 6.70$ & $49.7 \pm 10.4$ & $97.4 \pm 1.80$ \\
$10 \mathrm{mM}$ caffeine & $66.8 \pm 19.1$ & $68.5 \pm 19.0$ & $46.2 \pm 26.1$ \\
$10 \mathrm{mM}$ caffeine+1 mM catechin & $17.7 \pm 13.8$ & $35.7 \pm 10.7$ & $22.4 \pm 10.9$ \\
$10 \mathrm{mM}$ caffeine $+2.5 \mathrm{mM}$ catechin & $16.6 \pm 10.8$ & $72.6 \pm 22.3$ & $24.9 \pm 8.38$ \\
\hline
\end{tabular}

Values are means \pm SD 

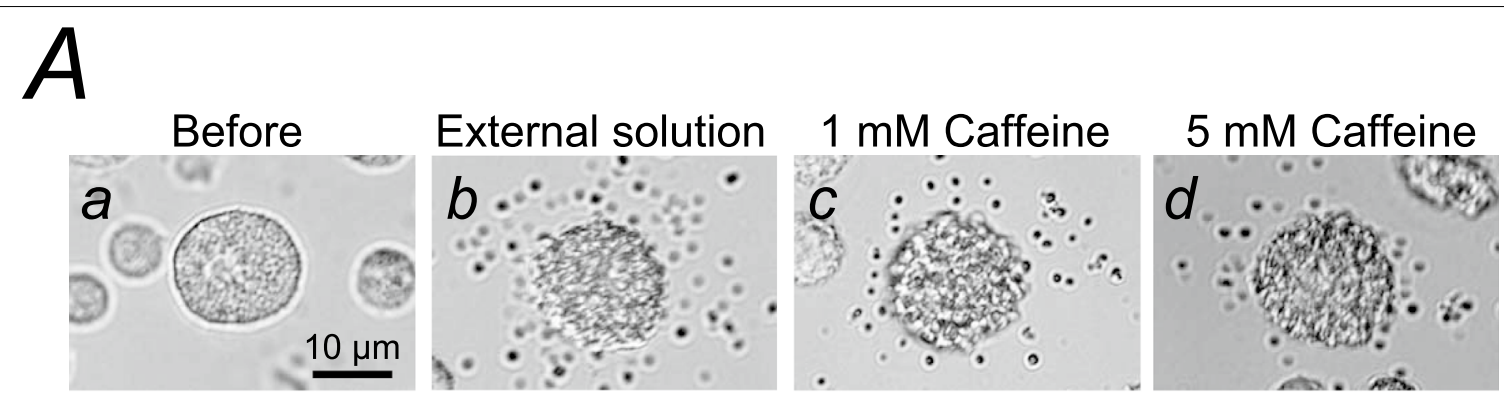

$10 \mathrm{mM}$ Caffeine
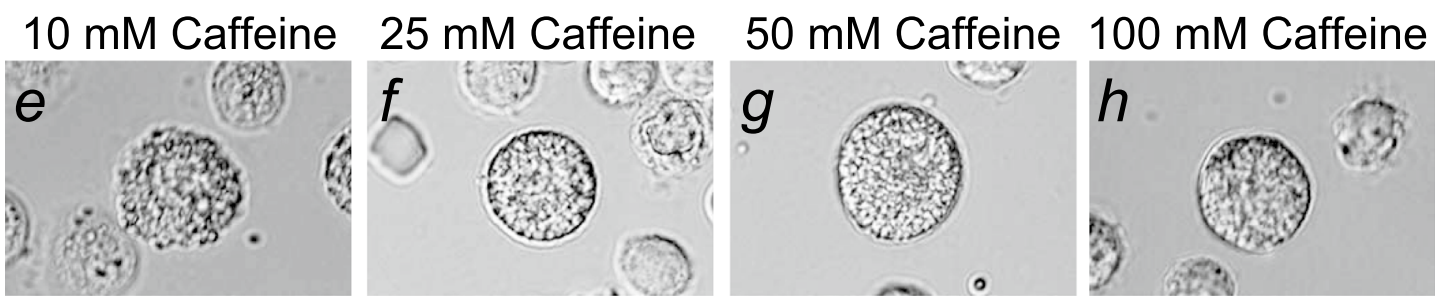

$B$

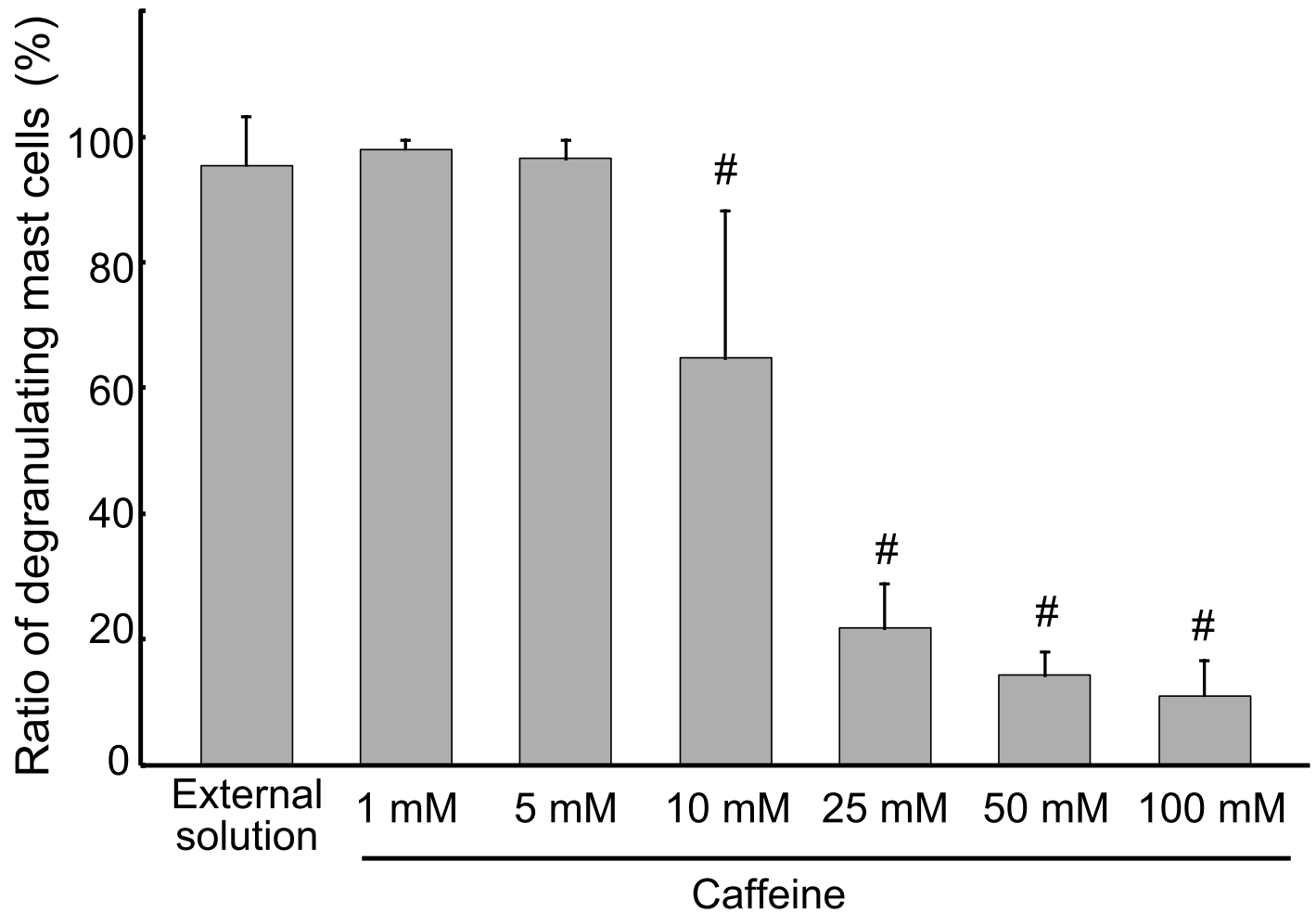

Fig. 1 Effects of caffeine on mast cell degranulation. A Differential-interference contrast (DIC) microscopic images were taken before (a) and after exocytosis was externally induced by compound 48/80 in mast cells incubated in the external solutions containing no caffeine (b), 1 mM caffeine (c), $5 \mathrm{mM}$ caffeine (d), $10 \mathrm{mM}$ caffeine (e), $25 \mathrm{mM}$ caffeine ( $\mathrm{f}$ ), $50 \mathrm{mM}$ caffeine $(\mathrm{g}$ ) and $100 \mathrm{mM}$ caffeine (h). B After the mast cells were incubated in the external solutions containing no caffeine or different concentrations $(1,5,10,25,50$ and $100 \mathrm{mM})$ of caffeine, exocytosis was induced by compound 48/80. The numbers of degranulating mast cells were expressed as percentages of the total mast cell numbers in selected bright fields. ${ }^{\#} p<0.05$ vs. incubation in the external solution alone. Values are means \pm SD. Differences were analyzed by ANOVA followed by Dunnett's $t$ test 


\section{A}

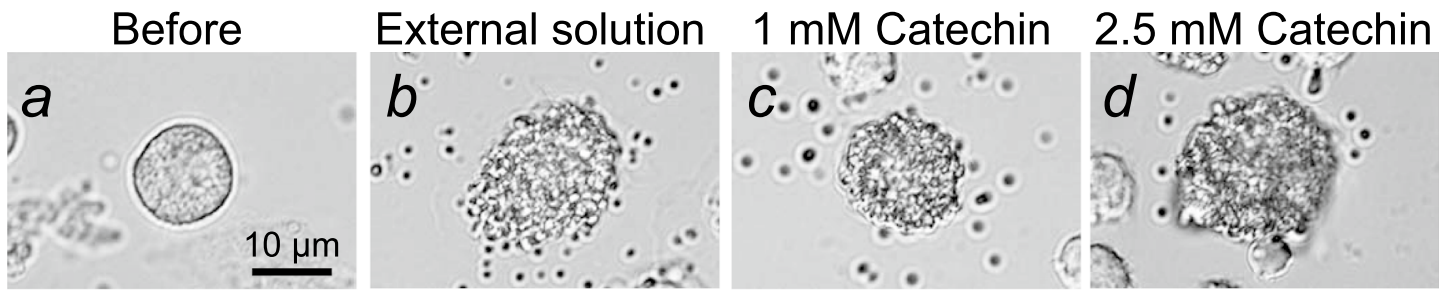

\section{$5 \mathrm{mM}$ Catechin}
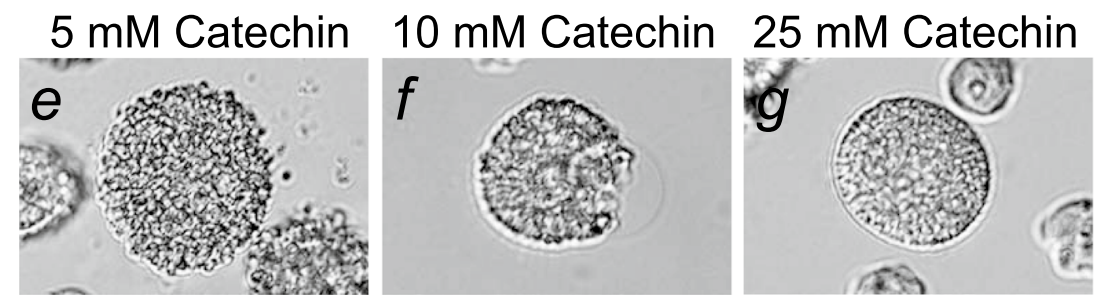

$B$

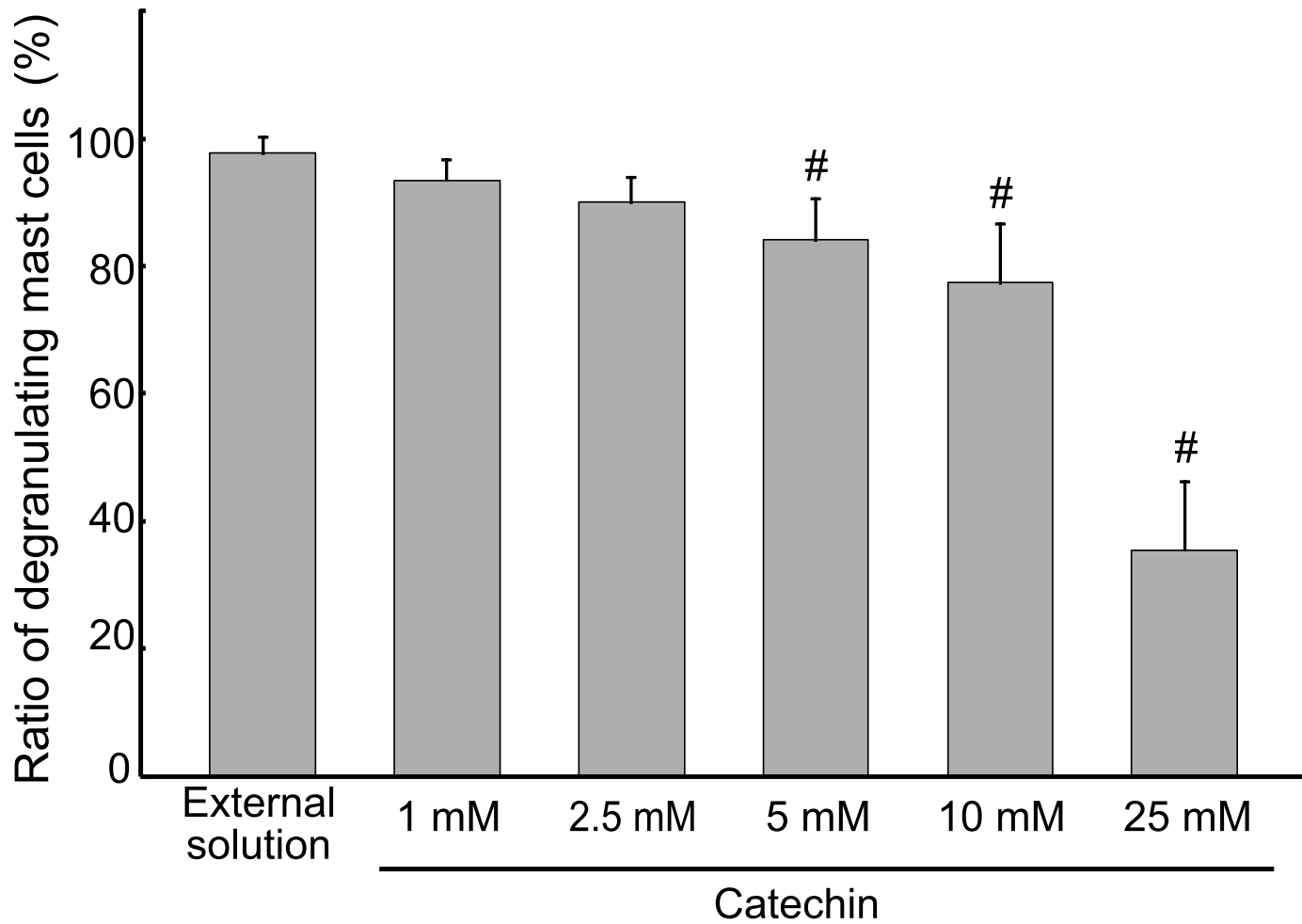

Fig. 2 Effects of catechin on mast cell degranulation. A Differential-interference contrast (DIC) microscopic images were taken before (a) and after exocytosis was externally induced by compound $48 / 80$ in mast cells incubated in the external solutions containing no catechin (b), 1 mM catechin (c), $2.5 \mathrm{mM}$ catechin (d), $5 \mathrm{mM}$ catechin (e), $10 \mathrm{mM}$ catechin (f) and $25 \mathrm{mM}$ catechin (g). B After the mast cells were incubated in the external solutions containing no caffeine or different concentrations (1,2.5, 5, 10 and $25 \mathrm{mM})$ of catechin, exocytosis was induced by compound 48/80. The numbers of degranulating mast cells were expressed as percentages of the total mast cell numbers in selected bright fields. " $p<0.05$ vs. incubation in the external solution alone. Values are means \pm SD. Differences were analyzed by ANOVA followed by Dunnett's $t$ test 
of chemical mediators, including histamine, leukotrienes or $\beta$-hexosaminidase, mast cells generate various types of inflammatory cytokines or growth factors [16]. In this regard, to accurately define the ability of caffeine or catechin on the stabilization of mast cells, the release of all these substances have to be evaluated. Otherwise, the exocytotic process itself has to be monitored directly in mast cells. In the present study, we carefully observed the whole process of exocytosis under the microscope and actually counted the numbers of degranulating mast cells. Thus, we provided direct evidence for the first time that both caffeine and catechin dose-dependently inhibited the process of exocytosis and thereby exerted mast cellstabilizing properties.

From our results, despite the lack of statistical significance, relatively lower concentrations of catechin $(1,2.5 \mathrm{mM})$ tended to decrease the numbers of degranulating mast cells (Fig. 2B). In our recently study, low dose prazosin, an $\alpha_{1}$-adrenergic receptor blocker, potentiated the ability of adrenaline, the first choice medication for anaphylaxis, to stabilize mast cells [13]. Therefore, expecting the similar additive therapeutic efficacy by low dose substances, we examined the effects of 1 or $2.5 \mathrm{mM}$ catechin on the caffeine-induced inhibition of exocytosis (Fig. 3). Consistent with our results shown in Fig. 1B, $10 \mathrm{mM}$ caffeine significantly but not markedly reduced the number of degranulating mast cells (control, $97.4 \pm 1.80 \%$ vs. $10 \mathrm{mM}$ caffeine, $46.2 \pm 26.1 \% ; n=10$, $P<0.05$; Fig. 3B). However, surprisingly enough, in the presence of 1 or $2.5 \mathrm{mM}$ catechin, the exocytotic process of mast cells was almost completely halted (Fig. 3Ac, d vs. b). Regarding the numbers of degranulating mast cells, they were more markedly decreased than those with $10 \mathrm{mM}$ caffeine alone (10 mM caffeine $+1 \mathrm{mM}$ catechin, $22.4 \pm 10.9 \%$, $n=34, P<0.05 ; 10 \mathrm{mM}$ caffeine $+2.5 \mathrm{mM}$ catechin, $24.9 \pm 8.38 \%, \quad n=10, \quad P<0.05 ; \quad$ Fig. $3 \mathrm{~B}), \quad$ showing that the inhibitory effect of caffeine on exocytosis was augmented. These results suggested that lower concentrations of catechin can synergistically potentiate the mast cell-stabilizing property of caffeine.
In mast cells, as we demonstrated in patch-clamp studies [10], an increase in the intracellular $\mathrm{Ca}^{2+}$ concentration $\left(\left[\mathrm{Ca}^{2+}\right]_{\mathrm{i}}\right)$ is the primary trigger of exocytosis [17]. According to several in vitro studies, caffeine and catechin suppress the elevation of $\left[\mathrm{Ca}^{2+}\right]_{\mathrm{i}}$ either directly or through the activation of adenylate cyclase and the subsequent increase in the intracellular cyclic adenosine monophosphate (cAMP) $[5,6]$. Recently, Nishikawa et al. additionally revealed the involvement of reactive oxygen species (ROS) in the effect of catechin on mast cell degranulation [15]. In their study, catechin exerted dual effects depending on the levels of intracellular ROS. When intracellular ROS level was low, catechin paradoxically suppressed the degranulation of mast cells. In the present study, 1 or $2.5 \mathrm{mM}$ catechin alone was not enough to decrease the numbers of degranulating mast cells (Fig. 2B). However, in the presence of $10 \mathrm{mM}$ caffeine, a potent scavenger of ROS [18], these concentrations of catechin remarkably reduced the numbers of degranulating mast cells (Fig. 3B). From these findings, caffeine-induced decrease in the intracellular ROS level was thought to elicit the ability of low concentrations of catechin to stabilize mast cells, which in turn synergistically potentiated the mast cell-stabilizing property of caffeine itself.

In our series of patch-clamp studies, by detecting the changes in whole-cell membrane capacitance $(\mathrm{Cm})$ in mast cells, we provided electrophysiological evidence that anti-allergic drugs, anti-microbial drugs and corticosteroids inhibit the process of exocytosis, and thus exert mast cell-stabilizing properties [9-13]. Using the same approach in the future, we could more elaborately determine the mast cell-stabilizing property of caffeine or catechin.

In summary, this study provided direct evidence for the first time that caffeine and catechin dosedependently inhibit the process of exocytosis. At relatively lower concentrations, caffeine or catechin alone did not stabilize mast cells. However, low concentrations of catechin synergistically potentiated the mast cell-stabilizing property of caffeine. 


\section{A}

External solution $10 \mathrm{mM}$ Caffeine
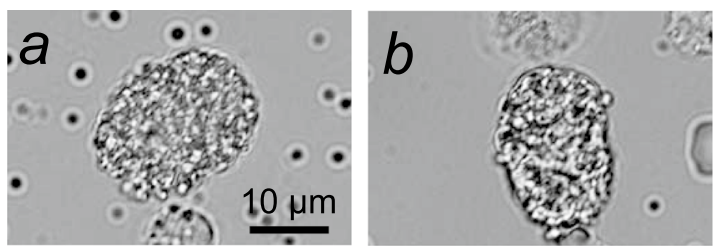

$10 \mathrm{mM}$ Caffeine $10 \mathrm{mM}$ Caffeine $1 \mathrm{mM} \stackrel{+}{\text { Catechin }} 2.5 \mathrm{mM} \stackrel{+}{\text { Catechin }}$
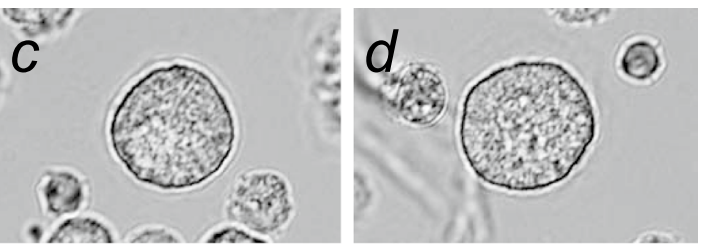

$B$

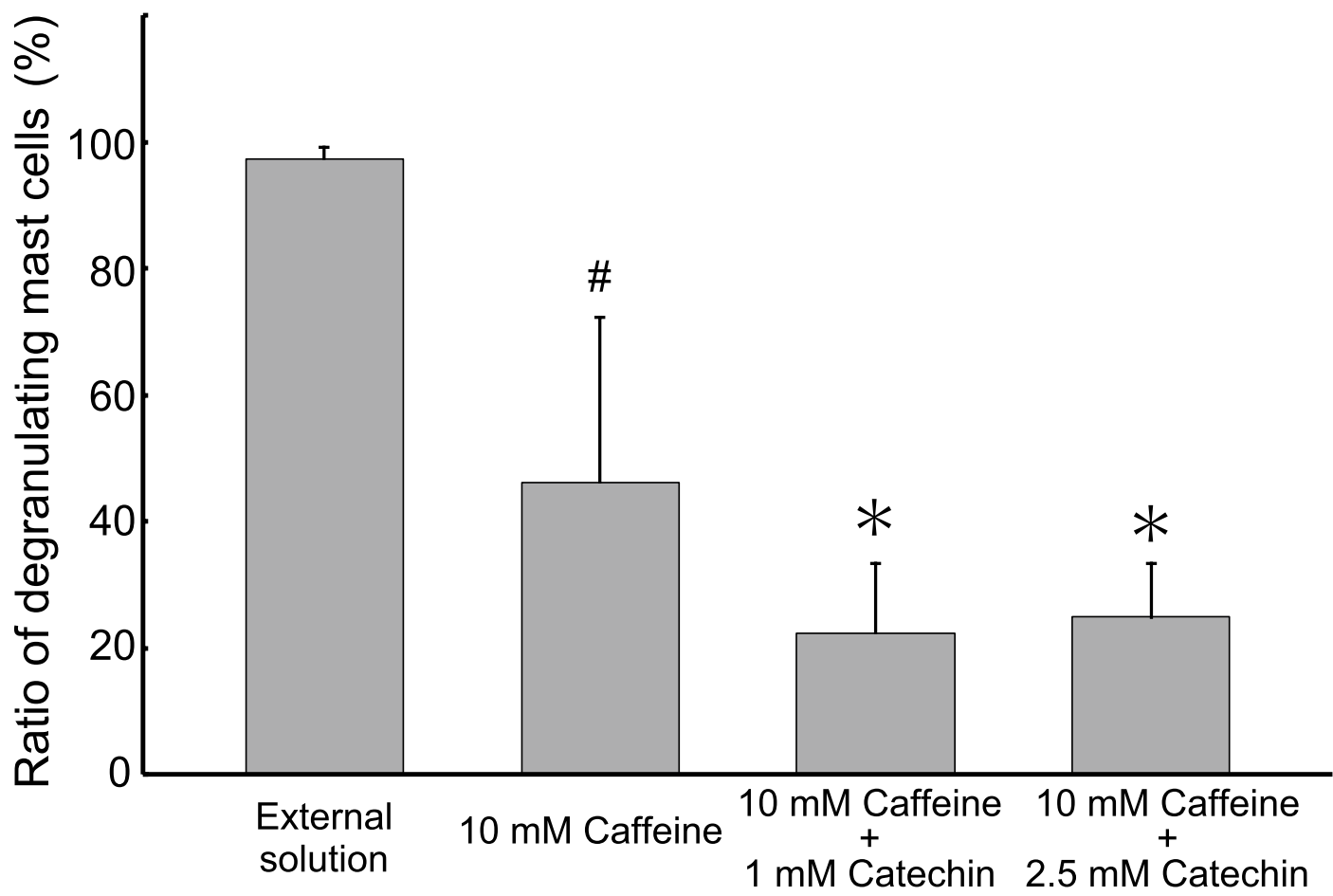

Fig. 3 Effects of low concentrations of catechin on caffeine-induced inhibition of mast cell degranulation. A Differential-interference contrast (DIC) microscopic images were taken after exocytosis was externally induced by compound $48 / 80$ in mast cells incubated in the external solutions containing no substances (a), $10 \mathrm{mM}$ caffeine alone (b), $10 \mathrm{mM}$ caffeine in the presence of $1 \mathrm{mM}$ catechin (c) and $10 \mathrm{mM}$ caffeine in the presence of $2.5 \mathrm{mM}$ catechin (d). B After exocytosis was induced in mast cells incubated in the external solutions containing no substances, $10 \mathrm{mM}$ caffeine alone, $10 \mathrm{mM}$ caffeine in the presence of 1 or $2.5 \mathrm{mM}$ catechin, the numbers of degranulating mast cells were expressed as percentages of the total mast cell numbers in selected bright fields. ${ }^{\#} p<0.05$ vs. incubation in the external solution alone. ${ }^{*} p<0.05$ vs. incubation in the external solution containing $10 \mathrm{mM}$ caffeine alone. Values are means \pm SD. Differences were analyzed by ANOVA followed by Tukey's test 


\section{Acknowledgements}

We thank Ms. Sanae Matsunaga and Mr. Makoto Shimoyama for their technical support.

\section{Authors' contributions}

MY and YS performed the experiments and analyzed the data. IK designed the experiments, interpreted the results and wrote the paper. All authors read and approved the final manuscript.

\section{Funding}

This work was supported by MEXT KAKENHI Grant, No. 16K08484, the Salt Science Research Foundation, No. 2028, the Tojuro lijima Foundation for Food Science and Technology, No. 2019-12 and the Cooperative Study Program (19-305) of National Institute for Physiological Sciences to IK.

\section{Availability of data and materials}

The data used to support the findings of this study are available from the corresponding author upon request.

\section{Ethics approval and consent to participate}

In isolating mast cells from the peritoneal cavity of male Wistar rats, we profoundly anaesthetized the animals with isoflurane and sacrificed them by cervical dislocation. The study was performed in accordance with the guide for the care and use of laboratory animals of Miyagi University, which included ethical considerations. The protocols for the use of the animals were approved by the Animal Care and Use Committee of Miyagi University (Protocol number: 2020-04-01).

\section{Consent for publication}

Not applicable.

\section{Competing interests}

The authors declare that they have no competing interest.

Received: 27 September 2020 Accepted: 8 December 2020

Published online: 06 January 2021

\section{References}

1. Yu NY, Bieder A, Raman A, Mileti E, Katayama S, Einarsdottir E, et al. Acute doses of caffeine shift nervous system cell expression profiles toward promotion of neuronal projection growth. Sci Rep. 2017;7:11458.

2. Narumi K, Sonoda J, Shiotani K, Shigeru M, Shibata M, Kawachi A, et al. Simultaneous detection of green tea catechins and gallic acid in human serum after ingestion of green tea tablets using ion-pair highperformance liquid chromatography with electrochemical detection. J Chromatogr B Analyt Technol Biomed Life Sci. 2014:945-946:147-53.

3. Buldak RJ, Hejmo T, Osowski M, Buldak L, Kukla M, Polaniak R, et al. The impact of coffee and its selected bioactive compounds on the development and progression of colorectal cancer in vivo and in vitro. Molecules. 2018;23:3309.

4. Cai ZY, Li XM, Liang JP, Xiang LP, Wang KR, Shi YL, et al. Bioavailability of tea catechins and its improvement. Molecules. 2018;23:2346.

5. Shin HY, Lee CS, Chae HJ, Kim HR, Baek SH, An NH, et al. Inhibitory effect of anaphylactic shock by caffeine in rats. Int I Immunopharmacol. 2000;22:411-8.

6. $\mathrm{Li} \mathrm{GZ}$, Chai $\mathrm{OH}$, Song $\mathrm{CH}$. Inhibitory effects of epigallocatechin gallate on compound 48/80-induced mast cell activation and passive cutaneous anaphylaxis. Exp Mol Med. 2005;37:290-6.

7. Welsh EJ, Bara A, Barley E, Cates CJ. Caffeine for asthma. Cochrane Database Syst Rev. 2010. https://doi.org/10.1002/14651858.CD001112. pub2CD001112.

8. Bani D, Giannini L, Ciampa A, Masini E, Suzuki Y, Menegazzi M, et al. Epigallocatechin-3-gallate reduces allergen-induced asthma-like reaction in sensitized quinea pigs. J Pharmacol Exp Ther. 2006;317:1002-11.

9. Baba A, Tachi M, Maruyama Y, Kazama I. Olopatadine inhibits exocytosis in rat peritoneal mast cells by counteracting membrane surface deformation. Cell Physiol Biochem. 2015;35:386-96.

10. Baba A, Tachi M, Ejima Y, Endo Y, Toyama H, Matsubara M, et al. Antiallergic drugs tranilast and ketotifen dose-dependently exert mast cellstabilizing properties. Cell Physiol Biochem. 2016;38:15-27.

11. Mori T, Abe N, Saito K, Toyama H, Endo Y, Ejima Y, et al. Hydrocortisone and dexamethasone dose-dependently stabilize mast cells derived from rat peritoneum. Pharmacol Rep. 2016;68:1358-65.

12. Kazama I, Saito K, Baba A, Mori T, Abe N, Endo Y, et al. Clarithromycin dose-dependently stabilizes rat peritoneal mast cells. Chemotherapy. 2016;61:295-303.

13. Abe N, Toyama H, Ejima Y, Saito K, Tamada T, Yamauchi M, et al. Alpha 1-adrenergic receptor blockade by prazosin synergistically stabilizes rat peritoneal mast cells. Biomed Res Int. 2020;2020:3214186.

14. Shimoda T, Liang Z, Suzuki H, Kawana S. Inhibitory effects of antipsychotic and anxiolytic agents on stress-induced degranulation of mouse dermal mast cells. Clin Exp Dermatol. 2010;35:531-6.

15. Nishikawa H, Kitani S. Tea catechins have dual effect on mast cell degranulation induced by compound 48/80. Int Immunopharmacol. 2008:8:1207-15.

16. Gruber BL. Mast cells in the pathogenesis of fibrosis. Curr Rheumatol Rep. 2003;5:147-53

17. Kuehn HS, Gilfillan AM. G protein-coupled receptors and the modification of FcepsilonRI-mediated mast cell activation. Immunol Lett. 2007:113:59-69.

18. Ko J, Kim JY, Kim JW, Yoon JS. Anti-oxidative and anti-adipogenic effects of caffeine in an in vitro model of Graves' orbitopathy. Endocr J. 2020;67:439-47.

\section{Publisher's Note}

Springer Nature remains neutral with regard to jurisdictional claims in published maps and institutional affiliations.
Ready to submit your research? Choose BMC and benefit from

- fast, convenient online submission

- thorough peer review by experienced researchers in your field

- rapid publication on acceptance

- support for research data, including large and complex data types

- gold Open Access which fosters wider collaboration and increased citations

- maximum visibility for your research: over 100M website views per year

At $\mathrm{BMC}$, research is always in progress.

Learn more biomedcentral.com/submissions 